VOLUME 12 No 2 (2021)

\title{
COMPARATIVE PHILOSOPHY
}

An International Journal of Constructive Engagement of Distinct Approaches toward World Philosophy

\section{OPEN ACCESS}

www.comparativephilosophy.org

ISSN 2151-6014 